\title{
Marketing Authorization
}

National Cancer Institute

\section{Source}

National Cancer Institute. Marketing Authorization. NCI Thesaurus. Code C156642.

A license issued by a regulatory authority that allows a medicinal product to be put on the market. 